\title{
Acting out: Literature, drama, and connecting with history
}

Drama engages students with literature in a way that simply reading printed words

cannot.

1 $\mathrm{s}$ the nationwide focus on preparing students for standardized tests intensifies in the United States, and budget cutbacks decimate school arts programs, drama is increasingly looked upon as a frill in elementary schools-an enrichment activity that teachers might lead on Friday afternoons after the important work is done for the week. But dramatic engagement can greatly enhance students' understanding of the stories they read, adding a depth and dimension to the plot, setting, and characters that simply reading the printed words rarely accomplishes. Moreover, drama can be the perfect vehicle for integrating reading with other areas of the curriculum. In particular, acting out historical stories in the classroom can bring history to life in powerful and exciting ways.

For many young students, eras and events of the past seem totally unrelated to their lives. But by acting out those stories, students can get intensely involved in history - disturbed, excited, and committed to learning more about the subject-while seeing how their lives in the present are connected to issues and concerns of the past. As Booth (1985) wrote, "Through drama, teachers help children acquire the means to more fully understand what they have experienced. Students need to interact with both the author's thoughts and their own thoughts in order to bring about true learning" (p. 195). This is exactly what happened when we (Georgia and John), a teacher and university professor, introduced Georgia's first graders to folk tales and his- torical fiction and helped them develop, rehearse, and perform plays based on the stories they read.

\section{Planning and implementing the curriculum}

Forest Glen School (all place and student names are pseudonyms) where Georgia teaches is a $\mathrm{K}-8$ school located in a rural northern California resort area. In spite of the tourist trade during the summer months, many of the town's year-round residents live in substandard houses that often flood during the winter's rainy season. Many students at the school are among the poorest children in the county.

The two of us first met a few years ago when John's son was a student in Georgia's first-grade class. Of the 11 boys and 7 girls in Georgia's class, 16 were of European American descent, 1 was African American, and 1 was Latina. With John acting as a parent helper in the classroom, we worked together on a number of projects, including writers' workshop and a science inquiry unit. Our most challenging collaborative endeavor, which is the focus of this article, grew out of our ongoing conversations about literacy (Georgia's area of expertise) and social studies and drama (John's areas of expertise). Over the course of many years in the classroom, Georgia had developed a successful reading and language arts program. But she had always taught social studies as an isolated subject and had never used her skills and knowledge as a reading teacher in her social studies curriculum. Therefore, for this project, we decided to plan and implement an integrated unit centered on historical plays that the first graders would write, stage, 
and perform for the rest of the school. A mutual interest in African American history and literature provided a focal point for our collaboration: How could we use literature and drama to help Georgia's first graders learn about (and find meaning in) African American experiences and perspectives?

Early in the school year we met over a period of weeks to plan our project. We read and discussed scores of picture books (many of which we've listed in Table 1) before finally organizing them into three categories that the students would explore in depth in the unit: life and culture in Africa (folk tales, history, geography); slave life in America (plantation life, slave rebellions, Underground Railroad); and the U.S. Civil Rights movement (Rosa Parks and the bus strike, Martin Luther King, Jr., school integration). Eventually we settled on two books from each time period to introduce the unit: Who's in Rabbit's House? (Aardema, 1997) and A Story, a Story (Haley, 1970) exemplified the rich literature and cultures of Africans in their homeland; Sweet Clara and the Freedom Quilt (Hopkinson, 1993) and Follow the Drinking Gourd (Winter, 1988) were stories about slaves escaping to the North; and two biographies, I Am Rosa Parks (Parks \& Haskins, 1997) and The Story of Ruby Bridges (Coles, 1995), vividly depicted key moments in the U.S. Civil Rights movement. After listening to and becoming familiar with these six stories, students would choose one from each time period to perform.

The topic of what specific standards to cover never came up in these conversations. Operating on Dorothy Heathcote's notion (cited in Wagner, 1976) that drama can "help children understand experience from the inside out" (p. 33), we focused entirely on planning engagements that we believed would be meaningful to Georgia's students. We were confident that the students' learning experiences would inevitably address a wide variety of California content standards (California State Board of Education, 2004a) in several subject areas: English language arts, history and social science, visual and performing arts, and perhaps even science. The resulting curriculum, we believe, justified this assumption. By the time the class concluded the plays, we had addressed most or all of the English language arts content standards (California State Board of Education, 2004b) in each of the four subcategories: reading (word analysis, reading comprehension, and literary response and analysis); writing (writing strategies and writing applications); written and oral Englishlanguage conventions; and listening and speaking (listening and speaking strategies and speaking applications [genres and their characteristics]).

When the unit began in January, John began team teaching with Georgia in the classroom two or three mornings a week. We also continued to meet regularly after school to debrief and plan. During the first week, we introduced and familiarized the students with each story. First, Georgia would read the story to the class, making sure to keep the students actively involved by asking them to predict what would come next in the story, to share their feelings about events in the story, to consider which parts of the story were fiction and which parts were historically accurate, and to respond to the story's conclusion. Following the reading and discussion of each book, we introduced an activity intended to help the students consider the themes and issues addressed in that particular story.

The activity we implemented for a book always arose out of the specific events or setting of that story. For example, students made a classroom map of Africa pieced together with patterns like those depicted in A Story, a Story and other African folk tales; they made African masks that were adapted from several different peoples and reminiscent of the masks worn by the actors in Who's in Rabbit's House? They also generated a freedom quilt and map of their own town to get an idea of how Clara accomplished this task in Sweet Clara and the Freedom Quilt, and they recreated the Big Dipper and other constellations after listening to Follow the Drinking Gourd. They wrote and discussed their responses to Ruby Bridges's school experiences, and they role-played the bus scene in $I$ Am Rosa Parks. Throughout that week, students also listened to excerpts from The Middle Passage (Feelings, 1995) in order to learn about the Africans' abduction from their homes into a life of slavery.

After reviewing all six of the stories, the students voted to perform Who's in Rabbit's House?, Follow the Drinking Gourd, and I Am Rosa Parks. We assigned parts according to students' requests and began work on the plays, asking questions such as "What do you think the character would say or do at this point?" Some of the students would 


\section{TABLE 1 \\ Picture books that can be used for plays}

Aardema, V. (1997). Who's in Rabbit's house? New York: Dial Books for Young Readers.

Adler, J.A. (1993). A picture book of Rosa Parks. New York: Holiday House.

Angelou, M. (1996). Kofi and his magic. New York: Clarkson N. Potter.

Benjamin, A. (1992). Young Harriet Tubman: Freedom fighter. New York: Troll.

Carter, P. (1990). Harriet Tubman and black history month. Englewood Cliffs, NJ: Silver Press.

Celsi, T.N. (1991). Rosa Parks and the Montgomery bus boycott. Brookfield, CT: Millbrook Press.

Chocolate, D.M.N. (1990). Kwanzaa. Chicago: Children's Press.

Chocolate, D.M.N. (1993). Spider and the sky god: An Akan legend. New York: Troll.

Coles, R. (1995). The story of Ruby Bridges. New York: Scholastic.

Dayrell, E. (1968). Why the sun and the moon live in the sky. New York: Scholastic.

Feelings, T. (1995). The middle passage: White ship, black cargo. New York: Dial Books for Young Readers.

Flournoy, V. (1985). The patchwork quilt. New York: Dial Books for Young Readers.

Geraghty, P. (1994). The hunter. New York: Crown.

Greenfield, E. (1995). Young Rosa Parks: Civil rights heroine. New York: Troll.

Grifalconi, A. (1986). The village of round and square houses. Boston: Little, Brown.

Haley, G.E. (1970). A story, a story: An African tale. New York: Atheneum.

Hopkinson, D. (1993). Sweet Clara and the freedom quilt. New York: Knopf.

Howard, E.F. (1991). Aunt Flossie's hats (and crab cakes later). New York: Clarion.

Isadora, R. (1979). Ben's trumpet. New York: Greenwillow.

Keats, E.J. (1965). John Henry, an American legend. New York: Pantheon.

King, M.L., Jr. (1983). The words of Martin Luther King, Jr. (selected by Coretta Scott King). New York: Newmarket Press.

Lowery, L. (1987). Martin Luther King Day. New York: Scholastic.

Marzollo, J. (1993). Happy birthday, Martin Luther King. New York: Scholastic.

McDermott, G. (1993). Anansi the spider: A tale from the Ashanti. New York: Scholastic.

McGovern, A. (1977). Wanted dead or alive: The story of Harriet Tubman. New York: Scholastic.

McKissack, P.C. (1988). Mirandy and Brother Wind. New York: Scholastic.

Medearis, A. (1995). The freedom riddle. New York: Dutton.

Miller, R.H. (1995). The story of Nat Love. Englewood Cliffs, NJ: Silver Burdett Press.

Mitchell, M.K. (1993). Uncle Jed's barbershop. New York: Simon \& Schuster.

Musgrove, M. (1976). Ashanti to Zulu: African traditions. New York: Dial Books for Young Readers.

Onyefulu, I. (1993). A is for Africa. New York: Puffin.

Parks, R., \& Haskins, J. (1997). I am Rosa Parks. New York: Dial Books for Young Readers.

Pinkney, A. (1994). Dear Benjamin Banneker. San Diego, CA: Harcourt Brace.

Ringgold, F. (1991). Tar beach. New York: Crown.

Ringgold, F. (1993). Aunt Harriet's Underground Railroad in the sky. New York: Crown.

Schroeder, A. (1996). Minty: A story of young Harriet Tubman. New York: Dial Books for Young Readers.

Turner, A. (1987). Nettie's trip south. New York: Macmillan.

Vega, E.H. (1995). The laughing river: A folktale for peace. Windsor, CA: Rayve Productions.

Walter, M.P. (1986). Justin and the best biscuits in the world. New York: Lothrop \& Lee.

Winter, J. (1988). Follow the drinking gourd. New York: The Trumpet Club.

232 The Reading Teacher Vol. 59, No. 3 November 2005 
actually refer to the book to ascertain what to say; others would deliver lines extemporaneously. Students not in the play watched and offered suggestions throughout the process. These preliminary scripts were continually evolving: Every time we practiced a play, we added new dialogue and actions. Members of each cast practiced their lines during the day; at home they practiced with parents and siblings. As the plays began to take shape, the energy in the room was electric.

Over the next several weeks, nearly every aspect of the curriculum revolved around the plays. For each play, students brainstormed to determine the costumes and props they would need, sound effects and music to include, and scenes to paint on the backdrop. Every student was involved in the decision-making process, and everything necessary for the play was student generated. For example, they modified the patterns of the African masks they had made earlier (adding animal characteristics) to create the masks for Who's in Rabbit's House? After listening to an audiotape of the song "Follow the Drinking Gourd," they learned the song and practiced singing it as a class; with parents assisting, they sewed a quilt for the "Quaker women" to be sewing along the Underground Railroad; and in the afternoons, they worked with Georgia on the backdrops. We began with a 6 ' wide by 30 ' long blank "canvas" of pieced-together sheets, divided in half lengthwise. Students painted the top part blue (for the sky) and the bottom brown (for the ground). Then they researched what should be depicted on the backdrop (city scenes for I Am Rosa Parks; forests, river, hills, and farms for Follow the Drinking Gourd; and so on), choosing appropriate pictures and drawing others that we converted into transparencies and projected onto large pieces of butcher paper. The students then traced the outlines onto the butcher paper and later used the outlines as guides for painting the pictures. After cutting out and laminating the pictures, Georgia and the students glued them onto the backdrop.

Student research was an integral component of all of these endeavors. Students consulted reference books to determine the flora and fauna for the Who's in Rabbit's House? backdrop; they searched out further information on the Birmingham, Alabama, bus boycott after reading I Am Rosa Parks; and they examined various maps to get a sense of the journey the characters undertake in
Follow the Drinking Gourd. Students frequently returned to the texts and pictures of the stories themselves, while listening to and examining other related works of fiction and nonfiction. In their zeal to create the most historically accurate renditions of these stories, the students became fully immersed in all aspects of the three productions.

Consulting several different texts not only facilitated their work on the plays but also helped students to learn that the plays were part of a broader historical context. Every day students were reading, writing, and drawing their reactions to what they were learning. They read various West African folktales about Anansi; they studied the Middle Passage, plantation life, and the Underground Railroad; they read about and discussed the accomplishments of many U.S. Civil Rights leaders and activists; and they wrote and illustrated stories in writers' workshop that reflected their evolving knowledge about and responses to African American history.

Georgia had never put on a play before and was at first hesitant to guide the actors. After watching John lead the students for the first few weeks, Georgia gradually took over, first just participating in the rehearsals, then codirecting, and eventually taking on primary responsibility. We rehearsed and performed the plays in Georgia's classroom. As the props, costumes, and backdrops took shape, the room gradually evolved into a theater. When it came time to perform the plays, we brought in enough chairs to fit an audience of about 50 . The small size of our theater required the students to do several performances over a few days. We performed for all the Forest Glen classes grades $\mathrm{K}-5$, and we culminated with an evening performance for parents and friends. Our original plan to perform all three plays at once proved too overwhelming, so we decided to work on one play at a time. As a consequence, the project became a semester-long effort, with performances in February, April, and June.

\section{Focus, motivation, and empowerment}

From the day we introduced this unit, the plays dominated classroom conversation; every morning the children would eagerly ask to rehearse or to work on related projects. It was great fun for them 
to immerse themselves in the roles of the characters they were portraying.

Consider, for example, the case of Jimmy. He was a difficult student to engage, a child who showed little interest in most schoolwork and had considerable trouble attending to tasks in the classroom. He often could not stay seated or focused for more than two minutes during storytime, and frequently he would start fooling around to distract his classmates during seatwork. But he loved participating in the plays. Not only did he remember his own lines, but he was also usually so attentive during rehearsals that we could count on him to remember other students' lines and to prompt them at the appropriate moment. When students were absent, Jimmy could fill in for them with ease.

Jimmy's body rhythms prevented him from concentrating on most school activities, but when operating in the realm of the theater he could focus for long periods of time. For Jimmy, as well as for other students, acting in the plays provided a way to step out of the usual student role and into the roles of others within boundaries and rules created by that imaginary situation. As "a more directed form of play" (Fox, 1987, p. 2), drama gave Jimmy and his classmates a way to perform with a level of concentration and self-discipline that we had not seen before in these first graders. Bodrova and Leong (1996) wrote, "Play helps children practice self-regulation. In play children cannot act any way they please, they must act in a way that conforms to the play scenario. Play requires significantly more control and deliberateness than other contexts" (p. 128). Acting provided this opportunity for the first graders.

Of course, producing the plays involved far more than just "play acting." These projects were intensely real and important endeavors for the students. From the outset, they saw these plays as their project, not ours: They chose which plays to perform, developed the scripts, and made it their business to take care of all the responsibilities (sound, props, backdrop, and so on) related to the productions. A curriculum like ours, based on genuine tasks, creates a cycle that promotes inspired and self-driven learners. As Short and Burke (1991) explained, "[The learners'] questions, not someone else's, initiate and motivate the learning process" (p. 16). When students take more responsibility for their learning, they begin to take ownership for their learning process; in turn, this sense of ownership reinforces their motivation and propels them on to new tasks.

Rebecca was one student who definitely felt a sense of ownership in the project. One day, as we were working on the backdrop for Follow the Drinking Gourd, she pointed out that we had forgotten to put the footprint and peg print of Peg Leg Joe on the trees. We didn't even know what she was talking about. "You know," she said, "like the words in the song." She sent us scurrying back to the book where we reread the song and found the verse that told of the slaves being guided to the north, not only by the constellation but by signs left by Peg Leg Joe, and so we added them to the backdrop. We had overlooked this significant detail, but fortunately, in this community of learners, Rebecca felt enough ownership in the project to take the initiative and teach us all. As Peterson (1992) explained,

The primary function of authority in a holistic learning community is not to control students or to require obedience, but to empower students to take the initiative, think for themselves, and assume responsibility for their own learning. Students who are empowered have the personal authority needed to express themselves confidently, judge their work and the interest of others. (p. 19)

Our students were empowered learners during this project. They were totally immersed in their productions throughout the semester, and they celebrated with enthusiasm and pride after our final performances because they were the creators, designers, and implementers of every aspect of each production.

\section{Authentic literacy tasks}

Literacy in all its forms is a major focus in any first-grade classroom. Throughout this process, Georgia did not abandon literacy instruction in hers. On the mornings that John did not come to Georgia's class, she led guided reading lessons to ensure that all learners were enhancing their reading and writing skills. However, literacy instruction should involve much more than merely the development of such skills. Producing the plays allowed students to engage in the search for meaning and 
experience the excitement and joy that literacy can bring to life.

In this unit, students were listening, speaking, reading, and writing not because they were being told to do so-and not merely in pursuit of particular standards - but because they were seeking to fulfill what they considered a pressing need to reach their goals for the plays. Their authentic engagement with literacy took many forms. They retold the stories in order to create the dialogue and scenes for the script, they revisited the books many times to make sure they were staying true to the story, they practiced the words from the song "Follow the Drinking Gourd" during class, they read the plays with their parents as homework and listened and followed along closely during rehearsals and performances of the play, and they wrote about the plays and African American history in their journals and stories for writers' workshop. Students found pictures of demonstration signs in some of the books about segregation and copied them as props for I Am Rosa Parks. In another African storybook they found a picture of a baobab tree, and, after a lengthy discussion about the type of tree it was and where it was found, they decided to include baobab trees in the backdrop to Who's in Rabbit's House? In a similar manner, they pored over several astronomy books to render the Big Dipper as precisely as possible on the backdrop for Follow the Drinking Gourd.

Students' ongoing engagement with the plays, requiring the continual telling, retelling, and acting out of the stories, accomplished far more than merely enhancing the children's basic language skills. As Bodrova and Leong (1996) explained,

By retelling familiar stories...children learn about general patterns common to all stories. Using these story patterns, called story grammar, involves putting events in logical sequence and understanding why a specific sequence is appropriate. By developing the idea of story grammar, children master basic logical concepts such as cause and effect, mutually exclusive events, and so on. (p. 146)

In strengthening their sense of story grammar, students were not just building some abstract skill: They were developing an understanding about logical sequence and cause and effect of actual historical events. The History-Social Science Framework for California Public Schools (History-Social
Science Curriculum Framework and Criteria Committee, 1997) asserted, "History [is] a story well told" (p. 4). Our students used language in its many forms in order to do just that - to make sense of, re-create, and share those stories. As Edelsky, Altwerger, and Flores (1991) explained, "Literacy is not an end in itself but a means for accomplishing ends. Learning to read and write is both part of and byproduct to learning and studying about the world" (p. 80).

\section{Connecting with history}

In this five-month unit, the first graders experienced history in a way that few of them ever had before. The stories they read and acted out stimulated their questions and their desire to read more and to share their knowledge with one another. Students became acquainted with Africa as a real and vibrant place. They learned about the brutal events that tore millions of Africans from their homeland and transported them to a life of enslavement on the other side of the world. They got glimpses of the lives of Southern slaves before the U.S. Civil War and the ordeals and triumphs that some of them experienced when escaping to freedom. They learned about life before and during the integration battles in the 1950s and 1960s and the individuals who bravely worked to make segregation a thing of the past. Their engagement with African American history recalls Nieto's (1996) advocacy for antiracist multicultural education:

\begin{abstract}
Although the beautiful and heroic aspects of our history should be taught, so must the ugly and exclusionary. Rather than viewing the world through rosecolored glasses, antiracist multicultural education forces both teachers and students to take a long, hard look at everything as it was and is, which also means considering the effects and interconnections among events, people, and things. (pp. 308-309)
\end{abstract}

Martha is an example of a student who took a long, hard look at African American history as it was and is. An eager participant in all three plays, Martha was a capable actress and an excellent reader; yet in I Am Rosa Parks, she frequently had difficulty delivering her lines in one scene, when she played a waitress who refuses to serve a black patron who comes in to sit at the counter. She was 
supposed to ask him rudely why he had come in and tell him in no uncertain terms to get out. Some days Martha would grimace and stutter her lines; other times she would not deliver the lines forcefully enough. One day, as we were encouraging her to speak louder and point to the door as she sent the patron out, Martha stopped in the middle of rehearsal and burst into tears. "I just can't do it," she sniffed. "I don't want to talk so mean to him. It's not right!"

Martha had not simply learned the historical information about discrimination in the 1950s and 1960s; she was, in a sense, living it as a member of the cast-and rejecting the accepted values of that time. She may have previously been aware of the existence of racism past and present, but it had had no meaning to her until she participated in the play. As Heathcote (1983) argued, "In drama the 'over there' becomes 'here' and the whole world is around me" (p. 695).

For Danny, rehearsing the plays initially caused more confusion than pain. His mother reported to us that one day, after he had begun rehearsal on Follow the Drinking Gourd, Danny went up to a local African American merchant and asked him if he was a slave. The man responded that he wasn't, after which the two of them engaged in a lengthy conversation about the man's ancestors and their experiences as slaves. For Danny, the initial confusion-caused by the contradiction between the content of the plays and what Danny was seeing on the streets of his town-led to his first meaningful conversation with an African American and a chance to communicate about the connections between and uniqueness of their respective cultural backgrounds.

Victor was another student for whom the plays must have been initially disturbing or confusing. The only African American student in the class, Victor at first offered few comments as he listened to the plays. Sometimes he would fool around and not pay attention. When we asked him questions about the stories, his responses were monosyllabic at best. But gradually he became increasingly involved in the project. He asked to be a rhino in Who's in Rabbit's House? It's a rich role for a good actor, yet hardly one that addresses the thornier issues of slavery and civil rights. Later, however, he asked to be a white rider on the bus in I Am Rosa Parks; the next day he asked to switch to playing a black rider, as well as the black man sent away from the lunch counter, and a black protester.

According to Verriour (1985),

In drama, the conventions of the theatre permit teachers to frame dramatic situations which not only make sense to children in terms of their understanding of the world but which also depict reality in such a way that they are challenged to become more reflective. (p. 185)

It is clear that over the months we worked on the play, Victor became more reflective about his identity and the relationship between the plays and his life. At home, he talked about his growing understanding of his historical and cultural roots; in the classroom, he started reminding the class that the plays were depicting stories of "his family." $\mathrm{He}$ told us, "Before the plays, I didn't know that African Americans were real." At first, the plays must have troubled Victor; later on, though, he understood their value to him and the rest of the class. As he often told us, the plays were showing not just history, but his story.

Developing connections with history can be confusing and at times deeply disturbing to students. But that discomfort can lead a learner to action. In exploring the literature and creating the plays based on what they read and discussed with one another, our students saw that oppression can be met with resistance, that "small heroes" (Ayers, 1990) like themselves can act in ways that change the course of history. By participating in this project, students came to see connections between their own lives and events of the past. They recognized that history is an organic and continuous process of which they too are a part.

\section{Produce a play of your own}

The plays were so popular at Forest Glen School that before long other teachers were producing plays of their own. "How did you do it?" Georgia's colleagues asked her. "What should I do to make the experience as successful in my classroom?" We were-and still are-hesitant to respond to such questions with a definitive list of dos and don'ts because to do so might limit the possibilities that others might consider.

Therefore, we offer the following suggestions, based on the elements that were key to our success, 
with the hope that teachers who endeavor to integrate literature, drama, and history will continually revise and augment the list.

- Start small. Three plays were too many for the first time, and they just about killed us; one is probably just right.

- Find someone (a friend, a parent) to work with you. Having someone to provide encouragement and with whom to exchange ideas-as well as to share in the workloadmade an otherwise overwhelming project doable and fun.

- Bring in the parents. Many of them love to take part in the process. Georgia now has a meeting each year with parents who would like to participate in the project. They help students pull together costumes, assist with rehearsals, guide students as they create and paint backdrops, and look for props that the students have identified.

- Don't start your planning with standards first. Standards are useful for reminding us of the skills and knowledge that we'd like students to develop, but taken out of the context of experience they hold little meaning for learners. We began this project with the goal of creating a meaningful learning experience for Georgia's students. Because they were engaged in authentic tasks that required them to develop and use many literacy skills, students met at least 41 of the 57 English language arts standards (California State Board of Education, 2004b) for their grade level, as well as many content standards in other subject areas - and with far more zeal than if they had instead been given worksheets to complete.

- Make sure that the topics explored in the literature (and, therefore, the plays) are meaningful and important to the students. Georgia's students easily related the themes in the stories to their own experience. They may not have experienced slavery in their lifetimes, but they had all seen unfairness and unkindnessas well as bravery and resourcefulness-at home and at school. Georgia's students cared about the events in the stories they read and performed because the issues connected to their own lives. The content of the curriculum must have importance in the lives of human beings in general and in the students' lives in particular.

- Allow the students to take charge of their learning. Our students were engaged not only because the content was relevant to their lives but also because they had ownership of the process. As Heathcote (1981) explained, drama "places decisions in the hands of the classes" (p. 89). Our students had choice and a voice in the direction of their learning: They chose the stories, developed the scripts, designed and created the backdrops, brought props from home, and chose the music. Don't expect perfection. The final result was a student project. Students and parents appreciated the idiosyncrasies that arose. That's what makes the productions memorable.

Integrating literature, drama, and history was no small undertaking, but it benefited our students in innumerable ways. Our project demonstrated that drama is not just a frill, something to be squeezed into the time left over after important instruction is done; it can engender vital and comprehensive learning experiences for students. Producing the plays reminded us that there are few limits to what even young students can accomplish. As teachers we must always remember to be grand in our vision and help students understand that the power to learn is not a chore but a joy to be found in themselves and working with others.

Kornfeld teaches at Sonoma State University, California (School of Education, $1801 \mathrm{E}$. Cotati Ave., Rohnert Park, CA 94928, USA). E-mail john.kornfeld@sonoma.edu. Leyden teaches first grade at Guerneville Elementary School in Guerneville, California.

\section{References}

Ayers, W. (1990). Small heroes: In and out of school with tenyear-old city kids. Cambridge Journal of Education, 20, 205-212.

Bodrova, E., \& Leong, D.J. (1996). Tools of the mind: A Vygotskian approach to early childhood education. Englewood Cliffs, NJ: Prentice Hall.

Booth, D. (1985). "Imaginary gardens with real toads": Reading and drama in education. Theory Into Practice, 24, 193-198. 
California State Board of Education. (2004a). Content standards. Retrieved January 3, 2005, from http://www. cde.ca.gov/be/st/ss

California State Board of Education. (2004b). Grade one English-language arts content standards. Retrieved January 3, 2005, from http://www.cde.ca.gov/be/st/ss/ enggrade1.asp

Edelsky, C., Altwerger, B., \& Flores, B. (1991). Whole language: What's the difference? Portsmouth, $\mathrm{NH}$ : Heinemann.

Fox, M. (1987). Teaching drama to young children. Portsmouth, NH: Heinemann.

Heathcote, D. (1981). Drama as education. In N. McCaslin, (Ed.), Children and drama (2nd ed., pp. 78-90). New York: Longman.

Heathcote, D. (1983). Learning, knowing, and languaging in drama: An interview with Dorothy Heathcote. Language Arts, 60, 695-701.
History-Social Science Curriculum Framework and Criteria Committee. (1997). History-social science framework for California public schools kindergarten through grade twelve. Sacramento, CA: California Department of Education.

Nieto, S. (1996). Affirming diversity: The sociopolitical context of multicultural education (2nd ed.). White Plains, NY: Longman.

Peterson, R. (1992). Life in a crowded place: Making a learning community. Portsmouth, NH: Heinemann.

Short, K.G., \& Burke, C. (1991). Creating curriculum: Teachers and students as a community of learners. Portsmouth, $\mathrm{NH}$ : Heinemann.

Verriour, P. (1985). Face to face: Negotiating meaning through drama. Theory Into Practice, 24, 181-186.

Wagner, B.J. (1976). Dorothy Heathcote: Drama as a learning medium. Washington, DC: National Education Association. 
Copyright of Reading Teacher is the property of International Reading Association. The copyright in an individual article may be maintained by the author in certain cases. Content may not be copied or emailed to multiple sites or posted to a listserv without the copyright holder's express written permission. However, users may print, download, or email articles for individual use. 